KYIV-MOHYLA

HUMANITIES JOURNAL

KYIV-MOHYLA SCHOLARLY PEER-REVIEWED JOURNALS

The Ukrainian "Galicia” Division: From Familiar to Unexplored Avenues of Research

Author(s): Myroslav Shkandrij

Source: Kyiv-Mohyla Humanities Journal 6 (2019): 1-23

Published by: National University of Kyiv-Mohyla Academy

http://kmhj.ukma.edu.ua/ 


\title{
The Ukrainian "Galicia" Division: From Familiar to Unexplored Avenues of Research
}

\author{
Myroslav Shkandrij \\ University of Manitoba, Department of German and Slavic Studies
}

\begin{abstract}
This article examines the main narratives that have dominated scholarly and political writings on the "Galicia" Division, the Waffen-SS 14th Grenadier Division that at the end of the Second World War was renamed the 1st Ukrainian Division of the Ukrainian National Army. Dominant narratives have focused on accusations of criminality, the hope that the formation would serve as the core of a national army at the war's end, survival as a motivation for signing up, the experience of the soldiers after their surrender to the British, and the decision to transfer former soldiers to the UK and then to give them civilian status. Only the first of these narratives has been explored in depth as a result of the 1986 Deschènes Commission of Enquiry into War Crimes in Canada and the 1989 Hetherington-Chalmers Report in the UK. Far less attention has been devoted to other narratives, and some lines of enquiry suggested by the rich memoir and creative literature have hardly as yet been touched.
\end{abstract}

Key Words: Ukrainian military, German army, "Galicia” Division, Second World War, history.

\section{(7)}

The Waffen-SS "Galicia” Division was created by the Germans mostly from Ukrainian volunteers in 1943-1944. After suffering heavy losses in the Battle of Brody in July 1944, it was reformed with new recruits and some soldiers taken from other military or police units. The Division was then deployed in Slovakia against a military revolt, in Slovenia in anti-partisan operations, and in Austria against the Red Army. It was renamed the 1st Ukrainian Division of the Ukrainian National Army shortly before it surrendered to the British and American forces at the end of the Second World War. The various narratives that discuss this military formation present contrasting views and sometimes conflicting accounts. A number of scholars have now produced studies on the Division. These have focused primarily on its wartime activity, ${ }^{1}$ or on the Division's postwar transfer from surrendered enemy personnel camps in Italy to the UK. ${ }^{2}$

1 See Michael O. Logusz, Galicia Division: The Waffen-SS 14th Grenadier Division 1943-1945 (Atglen, PA: Schiffer Pub., 1997); Andrii Bolianovskyi, Dyviziia “Halychyna." Istoriia [The History of the Galicia Division] (Lviv: IU, 200o); Michael James Melnyk, The History of the Galician Division of the Waffen-SS, 2 vols. (Stroud, UK: Fonthill, 2016).

$2 \quad$ See Olesya Khromeychuk, "Undetermined" Ukrainians. Post-War Narratives of the Waffen SS "Galicia" Division (Bern: Peter Land, 2013). 
The Division's genesis, wartime activities, and postwar fate have also been the focus of public debate, particularly in Canada at the time of the 1986 Deschènes Commission of Enquiry into War Crimes and in Britain during the 1989 HetheringtonChalmers Report. In contemporary Ukraine, discussion of the Division's history has raised broader issues concerning how the Second World War should be represented and how cultural memory politics can be negotiated. The discussion around the Division has also illustrated how cultural memory is reshaped over time, and also how it can be manipulated in an age of media management.

This paper examines two key questions that have framed the public discussionthe accusation of criminality and the justification for the Division's creation. It also suggests topics that need exploring in order to supplement and extend the existing scholarship. The biographies of individual members, the rich memoir literature, and the way different interpretative frameworks might be contextualized - all need investigating in order to help bridge existing narrative divides.

\section{First Narrative: Criminality}

A dominant narrative has focused on the issue of criminality. Several charges have been leveled: that, as a Waffen-SS formation, the organization should be seen as criminal by definition; that it was a tool of Nazi Germany and committed acts of violence against civilian populations; and that it harbored men who had committed war crimes elsewhere, prior to joining the Division.

As a blanket description of individuals in Waffen-SS Divisions the "criminal by definition" charge was rejected by both British and Canadian investigative commissions. The International Military Tribunal at Nuremberg did declare the Waffen-SS to be a criminal organization. It stated: "Units of the Waffen-SS were directly involved in the killing of prisoners of war and the atrocities in occupied countries. It supplied personnel for the Einsatsgruppen, and had command over the concentration camp guards after its absorption of the totenkopf SS, which originally controlled the system." ${ }^{3}$

Jules Deschènes, Commission of Inquiry on War Criminals. Report. Part 1: Public (Ottawa: Canadian Government Publishing Centre, 1986), 286. Armstrong is quoted in this context: "Himmler adopted the practice of awarding nominal Waffen SS status to personnel in other branches of his appanage, either for administrative reasons or to protect them from conscription. In 1944, for example, some 40,000 of the 60o,ooo members of the Waffen SS were employed in other components of the SS organization. More than half of them were assigned to the SS Economic and Administrative Main Office (SS-Wirtschafts und Verwaltungshauptamt or WVHA), which ran the concentration camp system. Although the concentration camp personnel were not under the command of Army or the Kommandoamt der Waffen SS, they wore Waffen SS uniforms and carried Waffen SS paybooks. Furthermore, there was a relatively limited but nevertheless continuous exchange of personnel between concentration camp staffs and the combat formations of the Waffen SS throughout the war. In short, the denials of the SS apologists notwithstanding, there existed a connection between the Waffen SS and 
However, the Commission found that this evidence was not relevant to every WaffenSS division or every individual who had served in these forces. Already on May 31, 1948 Flight Lieutenant Bohdan Panchuk, originally from Saskatchewan, who headed both the Ukrainian-Canadian Servicemen's Association and the Central Ukrainian Relief Bureau, stated in a memo:

In accordance with the general policy for all non-German "foreign" units, the unit was termed Waffen S. S. This should not, however, be mistaken for the actual German S. S. in which only "pure bred" Germans could serve. The Ukrainians were permitted to have priests in their units, they were not given any S. S. identity marks whatsoever and the terminology of their ranks and titles were those of the Wehrmacht. ${ }^{4}$

He pointed out that the Nuremberg Tribunal did not go into fine distinctions but declared the SS in general "a criminal organization," and a participant in war crimes and crimes against humanity. ${ }^{5}$ Despite this fact, the Tribunal imposed certain limitations and recognized exceptions.

The Deschènes Commission stressed that "Membership alone in the Waffen SS does not, in itself, amount to a crime under international law; it must be membership as qualified by the Tribunal in Nurnberg. It implies either knowledge or participation." 6 The Commission report, quoting Calvocoressi, also stated: "No individual can be punished without first having specific charges brought against him personally and without being brought before a court of law." 7 This was a blow to some members of the Jewish community who had argued the a priori criminality of all Division members. ${ }^{8}$

the concentration camps" (Deschènes, Commission of Inquiry on War Criminals, 248; John

A. Armstrong, Ukrainian Nationalism (New York: Columbia University Press, 1963), xxxii).

Deschènes, Commission of Inquiry on War Criminals, 255.

5 Deschènes, Commission of Inquiry on War Criminals, 256.

6 Deschènes, Commission of Inquiry on War Criminals, 257.

7 Deschènes, Commission of Inquiry on War Criminals, 257.

8 The Commission indicated that the Canadian Jewish Congress had already in 1950 provided a list of 94 suspects from the Galicia Division. "Unfortunately," the Commission stated, "no witnesses were offered in support of the allegations, and in exactly half the cases not even a first name was given to help identify the suspects" (Deschènes, Commission of Inquiry on War Criminals, 251). On September 25, 1950 the President of the Canadian Jewish Congress, Samuel Bronfman wrote that "each individual who was a member of the Halychyna Division ought to be stamped with the stigmata that is attached to the entire body of the SS" (Deschènes, Commission of Inquiry on War Criminals, 252). The Commission however agreed with the opinion of M. Yves Fortier: "If the only allegation against a resident of Canada is that he was a member of the Galicia Division that is not an individual which we consider should be made the subject of an investigation by your Commission. If the allegation is that while he was a 
When the Deschènes Commission issued its report in 1986, it noted: "Between 1971 and 1986, public statements by outside interveners concerning alleged war criminals residing in Canada have spread increasingly large and grossly exaggerated figures as to their estimated number." ${ }^{9}$ Sol Littman and Simon Wiesenthal were singled out as particularly persistent in advancing the figures of 3,00o and 6,00o.10 As for Wiesenthal's accusations, the Commission stated:

As already outlined, evidence of participation had not been forthcoming in 1950. In 1984, Simon Wiesenthal had supplied a list of 217 former members of the Galicia Division who, according to him, "survived the war and [were] not living in Europe." Since then the Commission has tried repeatedly to obtain the incriminating evidence allegedly in M. Wiesenthal's possession, through various oral and written communications with Mr. Wiesenthal himself and with his solicitor ... but to no avail: telephone calls, letters, even a meeting in New York between Mr. Wiesenthal and Commission Counsel on 1 November 1985 followed by further direct communications, have succeeded in bringing no positive results, outside of promises. ${ }^{11}$

The report explained that of the 217 names supplied, 187 never set foot in Canada, 11 came to Canada and died, 2 came to Canada and left for another country, 16 had no prima facie case, 1 was not located. ${ }^{12}$ The RCMP also received the same list in 1984 from Wiesenthal. The RCMP which conducted its own independent inquiry could find no evidence of war crimes against the 31 individuals on Wiesenthal's list of individuals who might have entered Canada. ${ }^{13}$

member of the Division, he committed atrocities at such-and-such a place, if there is evidence of the committing of atrocities alleged in the information which was conveyed to us, then that person becomes of interest to your Commission" (Deschènes, Commission of Inquiry on War Criminals, 254).

9 Deschènes, Commission of Inquiry on War Criminals, 249. The relevant chapters of the Commission's report are: chapter V "Relaxation of Restrictions on the Admission of Volksdeutsche and German Nationals," 204-15; chapter VII "Security screening, 1950-1951," 228-34; chapter VIII "Relaxation of Security Screening Guidelines with regard to Former Members of the Nazi Party, Wehrmacht and Waffen SS, and Nazi Collaborators, 1948-1953," 235-62; chapter XII, part 3, "Admission of the Ukrainian Halychyna (Galician) Waffen-SS Division," 366-408.

10 Deschènes, Commission of Inquiry on War Criminals, 248.

11 Deschènes, Commission of Inquiry on War Criminals, 257.

12 Deschènes, Commission of Inquiry on War Criminals, 258.

13 Deschènes, Commission of Inquiry on War Criminals, 258. 
On the issue of knowledge, the report stated that it could not be inferred that every individual must have known of slaughter on a gigantic scale, especially since "it is acknowledged the Division was used only in combat on the Eastern front from the middle of 1944." ${ }^{14}$ The report affirmed that the burden of proof was on the prosecution. It concluded that the Division should not be indicted as a group; its members had been individually screened and charges of war crimes had never been substantiated, either in 1950 or in 1984 when they were again renewed, or by the Commission; membership in the Division was insufficient to justify prosecution; no case for revocation of citizenship or deportation could be made; and the 217 officers of the Division denounced by Simon Wiesenthal put the RCMP and the Commission "to a considerable amount of purposeless work." 15

The public campaign against the Division peaked around 1983. Most accusations came from the Simon Wiesenthal Centre in the USA and Sol Littman in Canada. The campaign effectively ended when the Deschènes Commission issued its report in 1986. Littman was judged in a Canadian court to have slandered members of the Division and was instructed, as part of the court ruling, to stop defaming them. A Statement of Claim was issued in the Supreme Court of Canada on November 2, 1983 after an article by Sol Littman appeared in the July 1983 issue of Saturday Night entitled "Agent of the Holocaust, the Secret Life of Helmut Rauca." In it Littman had written:

Ultra-nationalist Ukrainians, Byelorussians, Georgians, Lithuanians, and Estonians formed their own SS units. Members of the Ukrainian Halychyna SS division helped put down the Warsaw ghetto uprising. Some of those who took refuge in Canada were among the many non-Germans who volunteered as concentration camp guards. Others were members of the punitive units and of the Einsatzkommandos that slaughtered thousands of Jews; still others

14 Deschènes, Commission of Inquiry on War Criminals, 258.

15 Deschènes, Commission of Inquiry on War Criminals, 258. The report examined individual cases, which it identified only by numbers, although it is clear that many were officers in the Division. It states, typically, in each case: "No evidence that the subject had entered Canada," "the Berlin Documentation Center ... had a record of the subject which confirmed only his membership in the Galicia Division of the Waffen-SS," "the Commission requested Mr. Wiesenthal to provide additional information with respect to the subject, and was advised that he was unable to do so," "it is recommended that the file on the subject be closed." In all, 776 cases on the Master List were looked at and reported on in this manner. The original Master List had been compiled from names provided by the Wiesenthal Center in Vienna (219 names) and Los Angeles (63), the Canadian Jewish Congress (and Prof. Irwin Cotler) (209), Sol Littman (171), B'nai Brith Canada (and David Mathas) (100), the Department of Justice Canada (81), the Canadian Holocaust Remembrance Association (54), the Israel Police (M. Russek) (54), the Jewish Federation of New Jersey (R. Krieger) (49), the USSR (43), and Ephraim Zufoff (29 names). Deschènes, Commission of Inquiry on War Criminals, 47-48. 
were civic and state officials in puppet governments that did the Nazi bidding. Some acted out of hatred for the Russians, some out of hatred for communism, some out of a naïve belief that the Germans would help them regain national freedom. All demonstrated an unquestioning acceptance of the centuries-old anti-Semitism endemic in their countries. Aware of the fate that awaited them at the end of the war, they fled to Canada. Some were granted entry on forged papers. Many relied on subtle name-changes to confuse the immigration department's primitive filing system. There is reason to believe that many passed through with the connivance of Canadian officials, acting on their own or in collaboration with American intelligence units such as the CIA. Communism had been the new menace. In any case the Canadian government had been reluctant to honour requests for their extradition. ${ }^{16}$

Littman had also published an article in the June 8, 1980 issue of the Toronto Sunday Star alleging that the Division had committed what he called "some of history's ugliest deeds." The Toronto Sunday Star was compelled to publish a retraction on August 17, 1980, in which it indicated that there was no record of the Division having engaged in atrocities or other war crimes, that its members had been individually screened by the United Nations, British, and Canadian authorities after the war and before admission to Canada, and that none were found to have committed any crime at all. The plaintiffs won their case under the Libel and Slander Act. In a speech given in 1997 Littman repeated some of his charges, but in a more modified form. ${ }^{17}$ Some of his accusations are repeated in his Pure Soldiers or Sinister Legion. The Ukrainian 14th Waffen-SS Division, where he expresses disagreement with the Nuremberg Tribunal's decision not to assign collective guilt ${ }^{18}$ and quotes from Soviet propaganda booklets, especially Valerii Styrkul's We Accuse, Serhii Danylenko's Dorohoiu hanby i zrady: istorychna khronika (Road of Shame and Treason: Historical Chronicle, 1970), Klym Dmytruk's Svastyka na sutanakh (Swastika on Cassocks, 1973) and Bezbatchenky (Fatherless, 1975), and Vitalii Maslovskyi's Zhovtoblakytna mafia (Yellow-Blue Mafia, 1975). Similar accusations had earlier been made by Petro Kravchuk (pseudonym Marko Terlytsia) in his Pravnuky pohani: ukrainski natsionalisty $v$ Kanadi (Bad Grandchildren: Ukrainian Nationalists in Canada, 1960), and his "Hanebna richnytsia" (Shameful Anniversary, 1973). These Soviet publications, it should be noted, are diatribes that provide no evidence and are full of factual errors. ${ }^{19}$

16 UCRDC, Toronto, Galicia Division files.

17 “Transcript of Sol Littman's Tryzub and Swastika Speech, 31 August 1997," accessed March 7, 2019, http://willzuzak.ca/lp/littma99.html.

18 Sol Littman, Pure Soldiers or Sinister Legion. The Ukrainian 14th Waffen-SS Division (London: Black Rose Books, 2003), 44.

19 John Kolasky, a fellow communist who broke from the party, explains that Kravchuk held paid positions and received dividends from the business controlled by the Soviet government and 
What is the evidence that members of the Division participated in anti-civilian violence? Several specific accusations have been leveled.

Publications in the 1970s accused the Division of involvement in atrocities against Polish civilians. ${ }^{20}$ Authoritative scholars have checked these accusations and rejected most of them, in particular the charge of involvement in the destruction of the Warsaw ghetto in 1943, and of putting down the Warsaw Uprising in August 1944. ${ }^{21}$ Ukrainian refutations of these charges include articles to the Polish journal Kultura by Liubomyr Ortynskyi and Borys Lewyckyj.22 They point out that when the Warsaw Uprising broke out 1 August 1944, the Division had just been crushed at Brody on July 21-22, 1944, so could not have taken part. ${ }^{23}$

the Canadian Communist Party. These included the Globe Tours travel agency, which had a monopoly on tours to Ukraine, the Taras investment company, which owned several business locations in Toronto, and the Ukrainska Knyha bookstore. He personally profited from all these. John Kolasky, The Shattered Illusion: The History of Ukrainian Pro-communist Organizations in Canada (Toronto: PMA Books, 1979), 212-14. For accusations see: Antoni Szcześniak and Wiesław Szota, Droga do nikąd. Wojna polska $z U P A(1973)$ in the section devoted to "The Division and Other Melnikite Military-Police Formations" (121-30); Zygmunt Klukowski, Dziennik z lat okupacji Zamojszczyzny (1958); Leszek Siemion, Z lat okupacji hitlerowskiej na Lubelszczyźnie (1971), 287-88; Czesław Madajczyk, Hitlerowski terror na wsi polskiej 1939-1945 (1965), 6-7; Antoni Szcześniak, "Niektore problemy stosunkow” (1968); Mieczysław Juchniewicz, “Z działalności organizacyjno-bojowej Gwardii Ludowej w obwodzie lwowskim" (1968), 153, and in his Polacy w radzieckim ruchu podziemnym ipartyzańskim 1941-1944 (1973), 27.

21 For example, Hanns von Krannhals, Der Warschauer Aufstand 1944 (1962) lists every military formation, but does not mention the Division, or any Ukrainian force. Neither does Jerzy Kirchmayer, Powstanie warszawskie (1964) or Jerzy Lovell, Polska jakiej nie znamy (1970). The latter writes: "no one anywhere has affirmed that the formations of the Division SS-Galicia or even the detachments of the Ukrainian police were involved in putting down the Warsaw Uprising; all Polish sources ... list only the Vlasovite 'Cossack-Brigade' and Kaminsky's RONA brigade." Jerzy Lovell, Polska, jakiej nie znamy: zbior reportazy o mniejszosciach narodowych (Krakow: Wydawnictwo Literackie, 1970), 70. Ryszard Torzecki, a Polish historian who has done archival research on the Division, also supports the argument that members of the Division did not participate in the suppression of the Warsaw Uprising. He indicates, however, that other aspects of Veryha's arguments call for further research. Ryszard Torzecki, Review of Dorohamy Druhoi Svitovoi Vïny: Lehendy pro uchast ukraintsiv $v$ Varshavskomu povstanni 1944 r. ta pro Ukrainsku dyviziiu 'Halychyna,' by Vasyl Veryha. Dzieje Najnowsze 123.4 (1981): 206-11. Borys Lewyckyj, "Ukraińcy a likwidacja Powstania Warszawskiego," Kultura (Paris) 6 (1952): $74-87$.

23 At the end of June 1944, however, just before the Division set off for the front at Brody, ten non-commissioned officers were sent to the officer-training school at Pozen-Traskaw. After a protest by the Division commanders, nine of the ten returned. They reported that they had been assigned as Polish speakers to the Vlasov forces for translation work, but on arrival had been kept with the German forces because these were unsure what to do with them. They took 
Charges have also been made against the Beyersdorf Batallion, a unit that was still completing training in February 1944 when it engaged Soviet and Polish partisans north of Lviv in the Lublin area. In this case we have a statement by Wolf-Dietrich Heike, one of the Division's commanders, that members of the Division, led by inexperienced commanders and still at the time poorly trained, were guilty of "unseemly behaviour." 24 However, the scholarship does not provide conclusive evidence that the Division was involved in any criminal behavior. ${ }^{25}$ The descriptions of relevant incidents in the memoirs of the Division's soldiers and eyewitnesses differ from the descriptions offered by Soviet sources. ${ }^{26}$

The Division has also been accused of participating in the massacre at Huta Pieniacka (Huta Pieniatska) near Brody on February 27-28, 1944, during which 5 oo Poles were killed. Roman Dolynskyi and Vasyl Veryha have challenged the early accounts, pointing out that the Polish exile government gave a different version of this event in 1944 and that Dmitrii Medvedev, the Soviet partisan leader, fails to mention the Division when describing this event in his memoirs Silnye dukhom (Strong of Spirit, 1963). ${ }^{27}$

no part in the action. One of their number, Klymiuk, had been born in Warsaw and while trying to get to the home of his parents, about whose fate he had not heard anything even before the outbreak of the Uprising, was killed somewhere on the streets of Warsaw. Vasyl Veryha, Dorohamy Druhoi svitovoi viiny: Legendy pro uchast ukraintsiv u Varshavskomu povstanni 1944 r. ta pro Ukrainsku Dyviziiu "Halychyna" [On the Paths of the Second World War: The Myths About the Participation of Ukrainians in the Suppression of the Warsaw Uprising and the Ukrainian Galicia Division] (Toronto: Shevchenko Scientific Society in Canada, 1981), 127.

Wolf-Dietrich Heike, The Ukrainian Division “Galicia," 1943-45: A Memoir (Toronto: Shevchenko Scientific Society, 1988), 22.

25 Khromeychuk, "Undetermined" Ukrainians, 68-89; Melnyk, The History of the Galician Division, 102-03.

26 See the Veryha Collection in the Provincial Archives of Ontario. File "Italy-Rimini. POW camps - Ukrainian division Galicia" contains a manuscript by Mykhailo Dliaboha, which includes an interesting chapter on the Bayersdorf group, which fought Kovpak partisans for 35 days. See also Roman Dolynskyi, "Boiova hrupa Baiersdorfa [The Baiersdorf Military Group]," Visti Bratstva kol. Voiakiv 1. UD UNA (Munich) 3-8 (1957): 77-80, and 7-10 (1957): 6-10.

27 Veryha, Dorohamy Druhoi svitovoi viiny, 459. See Sprawozdanie sytuacyjne z ziem wschodnich, Ministertwo Spraw Wewnętrznych, Wydział Spoleczny 12.44 (April-May, 1944), 45: "On the terrain of the lines near the front worked the competent and deceitful Secret Field Police (Geheine Feld Polizei GFP), which in many cases used provocative measures. The provocative TFP passed by the village of Huta Pieniacka on 24 February near Brody and the local inhabitants thinking this was a Ukrainian group (banda) began to shoot at it. As a result, 6-8 Germans were killed. On 27 February a punitive expedition of the TFP completely destroyed the village, killing around 5oo people" (quoted in: Veryha, Dorohamy Druhoi svitovoi viiny, 113). The next bulletin mentions Ukrainians: "When the Ukrainian SS conducted searches, the Poles... began to shoot at them." It then states that 5 oo Poles died and only 49 members of the village escaped (Sprawozdanie sytuacyjne, 15.44, 24). 
The Ukrainian journalist Oleksandr Matla, who tried to examine the facts and searched among Division members for eyewitnesses, has concluded that soldiers of the Division were involved in the military action but not in the ensuing punitive action against the village. ${ }^{28} \mathrm{He}$ believes that the Soviet special ops group under Krutikov left Huta Pieniacka three days before the destruction fully aware of what was to come. The survivors (19 according to Medvedev and 49 according the exile government) "found Krutikov." ${ }^{29}$ This suggests that the action might have been a deliberate provocation by Soviet partisans, who simply watched as the massacre took place in order to report it as an attack on civilians. Veryha has insisted that the initial attack was not on a peaceful village but on a well-armed force, and that the detachments who then destroyed the village and killed the remaining inhabitants were mainly composed of Germans. He argues that any Ukrainian troops who advanced on the village with the Germans were not under the Division's command at the time, and "therefore the statement that the Division Galicia took part in the pacification of that village and burned Poles alive does not correspond to facts." 30

It has also been charged that the Division was involved in anti-civilian violence both in late May 1944 in the Hrubieszów and Lublin areas, ${ }^{31}$ and during its time in Slovakia in August - October 1944. However, the evidence here requires further sifting. ${ }^{32}$

The Division has also been accused of participation in anti-Jewish violence. The suggestion has been made, for example, that some soldiers were used to round up Jews in Brody in February $1944 .^{33}$ It is certainly not impossible that such cases occurred. Moreover, in wartime situations "AIMs" (accidents, incidents and mavericks) are a relatively frequent occurrence. However, the evidence so far accumulated does not confirm that, as a military formation, the Division was instructed to participate in antiJewish violence, or that it was directly involved in anti-Jewish violence. ${ }^{34}$

28 O. Matla, "Sprava Huty Pieniatskoi i dzherela [The Huta Pieniacka Case and the Sources]," Visti kombatanta 1.93 (1978): 55 .

Matla, "Sprava Huty Pieniatskoi i dzherela," 6o.

30 Veryha, Dorohamy Druhoi svitovoi viiny, 115 .

$31 \quad$ Littman, Pure Soldiers or Sinister Legion, 77.

32 Dmytruk was a major of the KGB called Klymentii Halskyi. He was of Polish origin, from the Zhytomyr region, and had himself been accused of war crimes in the Lviv region, where he reportedly murdered prisoners and fabricating "cases" as required by the KGB. See the underground journal from Ukraine, Ukrainskyi visnyk 6 (March 1972) (reprinted Baltimore: Smoloskyp, 1972), 165-66; quoted in Veryha, Dorohamy Druhoi svitovoi viiny, 77. Dmytruk claimed falsely that Sheptytskyi and the Ukrainian Catholic Church hierarchy were largely responsible for the Division's creation, calling them traitors and enemies of the people: "In spite of all the efforts of the clergy the recruitment of volunteers dragged on" and "by 5 July only a few hundred collaborators had signed up" (quoted in Veryha, Dorohamy Druhoi svitovoi viiny, 78). Durchführung eines staatlischen Massen verbrechens (Munich: R. Oldenbourg Verlag, 1997), 363. 
On the other hand, the charge that some men might have participated in anticivilian violence prior to joining or being attached to the Division, either as members of police units, or guards, or guerrilla fighters, has been described as "highly credible." 35 It is widely accepted that before attachment to the Division, certain individuals and units had a history of violent, even sadistic behavior. The most notorious of these was the Dirlewanger Brigade, which joined the Division for the duration of counterinsurgent operations in Slovakia and was composed of "criminals and military convicts and was infamous for pillaging and looting." ${ }^{36}$ Therefore, although the Division was formally cleared of participation in "collective" war crimes, it certainly included some individuals with a dark past. Some of the most suspect units like the Dirlewanger Brigade, it should be noted, were not necessarily composed of Ukrainians and were temporarily attached to the Division. The criminality of this Brigade is not denied by the Division's historians, including former soldiers. ${ }^{37}$ Nor do these historians deny either the presence or the criminality of Ukrainians in the RONA (Russkaia Osvoboditelnaia Narodnaia Armiia) under the command of General Mieczysław Kamiński, or in the ROA (Russkaia Osvoboditelnaia Armiia) of General Vlasov. Both these military formations were present in Warsaw in 1943 and 1944.

Alti Rodal has indicated some further possible criminal behavior that might have occurred before some men joined the Division and that still needs investigating. She informs that according to German documents, the Ukrainian Constabulary (Schutzmannschaft) Battalion 204, stationed at the "Heidelager" SS training grounds where the Galician Division completed its training, was transferred to the Galician Division in January, 1944. She states that there are further documented instances of former members of "Schutzmannschaften" or auxiliary police battalions being integrated into the Galician Division after the battle at Brody in July 1944. ${ }^{38}$ Only 3,000 of the Division's 11,00o soldiers managed to break out of the Soviet encirclement at Brody. The remainder were either killed or taken prisoner, and some of the survivors joined the Ukrainian Insurgent Army. The Division was then reconstituted with those who remained. To these were added members of the independent SS-Police regiments, which had been formed from the overflow of recruits following the initial call for volunteers, but also from members of other reserve regiments, and from new recruits. ${ }^{39}$

According to a comprehensive memorandum on the Division prepared in May 1948 by Panchuk, "Ukrainians who had previously been drafted to other German units

35 Khromeychuk, "Undetermined" Ukrainians, 75.

36 Khromeychuk, "Undetermined" Ukrainians, 88.

37 Veryha, Dorohamy Druhoi svitovoi viiny.

38 Roger James Bender and Hugh Page Taylor, Uniforms, Organization and History of the Waffen-SS (San José, CA: R. James Bender Publishing, 1975), 39-40.

39 See: Alti Rodal, “The Ukrainian 'Halychyna' (Galician) Waffen-SS Division,” chapter XII, part 3. The information is taken from Bender and Taylor, Uniforms, Organization and History of the Waffen-SS, 39. Heike notes the inclusion of the Volyn Self-Defence Legion in the Division in February 1945 . 
were offered the opportunity to 'volunteer' for transfer from these German units to the Ukrainian Division." 40 These would have included individuals scattered throughout various German units in the 1941 to 1943 period. Rodal argues that the reconstitution of the Division after the battle of Brody, which added 12,00o men to the 3,00o remaining from the earlier formation, provided an opportunity for integration into the Division of persons with a war criminal background. As concerns anti-partisan activities, particularly during its period of duty in Slovakia and in Slovenia, Rodal argues that an assessment is required as to whether there were Jewish and other civilians among Soviet partisans in Slovakia and Tito's partisans in Slovenia, and what preoccupied the German security forces in these locations. ${ }^{41}$

The decision by the Hetherington and Deschènes commissions of enquiry to exonerate the Division from collective responsibility for any crimes, although essentially correct, was done without an investigation into the prior activities of all individual members. The lack of this further layer of detail has allowed speculation about criminal behavior to shadow later discussions of the Division. Nonetheless, it should be pointed out that the Division had already been examined in 1945 by Polish officers concerning its possible participation in the suppression of the Warsaw Uprising. While in SEP (Surrendered Enemy Personnel) camp in Rimini, Italy, in 1946-1947, the Division's members were also questioned by both Soviet and British officers. No evidence of criminality was found then or later.

Some of the above accusations, even those that have been thoroughly disproved, were repeated at regular intervals. The British screening procedures at the end of the war were criticized as superficial because they did not conduct a micro-analysis of each member's activities. This allowed the British and Canadian press periodically to use the presence of former Division members on its territories as an opportunity for sensationalist stories.

The influence of the media at the time of the Deschènes Enquiry (1986) and the Hetherington-Chalmers Report in Britain (1989) has not been studied. However, it is clear that the newspapers and television programs broadcast unverified and irresponsible claims that thousands of Nazis were living in Britain and Canada. Yorkshire Television produced a documentary entitled The SS in Britain, which was then aired on the History

40 LAC, RG76, v. 656, f. B 53802, pt. 1, Memorandum re: Ukrainian “Divisia Halychyna," May 31, 1948, p. 4 .

41 According to Heike, the Division trainees were formed into "Kampfgruppe Beyersdorff" in February 1944 in response to a request from Höhere SS und Polizeiführer in Kraków, for the purpose of anti-partisan activity in Northwest Galicia. This grouping operated in the following areas: Chesaniv, Liubachiv, Tarnohorod, Bilohrai and Zamostia. Heike, The Ukrainian Division “Galicia," 42-45. In early October 1944, the Division moved to Zilina (Slovakia) for anti-partisan warfare where regiments took part in assaults on Slovak partisans near Banska Bystrica. Heike, The Ukrainian Division “Galicia," 128. In February 1945, the Division took part in further anti-partisan operations in the area of Mozirje-Ljubro-Solvava. Heike, The Ukrainian Division “Galicia,"165-67. 
Channel in Canada on 24 September 1999, and tabloid headlines warned readers that their closest neighbors might be Nazi war criminals. One headlines reading "Do Nazi War Criminals Live on Your Street?" appeared alongside photos of goose-stepping SS troops.

It is important to note that these hysterical reports were sometimes used as cover for political projects. The Division's importance had always been more political than military. Its existence testified to the desire of Ukrainians to fight the Soviet Union, and by this very fact it denied legitimacy to Soviet war narratives. Consequently, Soviet authorities exploited the image of the Division as a criminal formation and attempted to spread guilt by association with the Division to any other group opposing rule from Moscow. By insisting that the Division consisted of society's dregs, Soviet authorities also sought to discredit the Ukrainian émigré community as a whole, including scholars and politicians whom they perceived as critical of the Soviet Union or Russia. This kind of propaganda, for example, surfaced in the 1970s when the Ukrainian émigré community mobilized in defense of dissidents, supported the publication of the Encyclopedia of Ukraine, or created university chairs. It resurfaced around 1983 when the émigré community marked the fiftieth anniversary of the Great Famine (Holodomor) of 1932-1933 and supported the publication of Robert Conquest's ground-breaking book on the topic. The value of the guilt by association tactic, of course, lies in its not requiring scholarly scrutiny; the lurid headlines intercut with photographs were often sufficient to throw a shadow on any critical voice and were regularly employed to discredit and intimidate scholars and journalists. Today, the tactic is still used. Articles featuring, for example, the grave sites of Division members in Canada appear whenever the government in Moscow feels it is necessary to undermine any initiative it considers to have originated with the Ukrainian "diaspora" in Canada.

\section{Second Narrative: Core of a National Army}

The discussion of possible criminality has been challenged by a second narrative, one that was initially widely circulated in the postwar emigration and is now familiar to many readers in post-independence Ukraine. It describes the creation of the Division as justified by the idea that at the end of the war it could become the nucleus of a national army. Many sectors of the population in Galicia and Western Ukraine at the time accepted news of the Division's creation with enthusiasm. This was not because they sympathized with fascism or believed in a German victory. In fact, the opposite was true: the defeat of Germany was expected and therefore the need for an army in the war's aftermath was viewed as a necessity. The Division, it was hoped, would play a role in the anticipated post-war chaos, in an analogous manner to the role the Ukrainian Sich Riflemen (Sichovi Striltsi), a professional army in the Austrian military, had played in the wake of the First World War, when it became the core of a national army and fought for an independent Ukraine. ${ }^{42}$ The main ideologist behind the Division's creation was, according to Veryha, the journalist and politician Dmytro Paliiv, a former 
Sich Rifleman and adjutant to General Myron Tarnavskyi, Commander in Chief of the Ukrainian Galician Army in 1920: "He hoped that the German failures on the front would lead to a revolution in Germany, which would then make peace with the Western allies and together with them would oppose the Soviet Union, which was propagating world revolution." 43

One of the Division's songs contained the words: "The volunteers are marching, Like the Riflemen did before. Their helmets play in the sun, a smile of freedom on their faces. Whoever is alive, join the ranks, to liberate and win our native land." 44

According to Kost Pankivskyi, the population and all leading politicians in Western Ukraine and the emigration had long dreamed of a professional Ukrainian army with its own commanding officers. ${ }^{45}$ Because the interwar Polish government had prevented Ukrainians from entering officer schools, throughout the 1930s, in anticipation of a conflict, nationalist forces had tried to obtain military training in various countries. There was a general understanding that at a crucial political moment foreign governments respect only a people and country that can demonstrate military capability. The desire to be a "partner, and not an agent of foreign powers" formed part of this logic. ${ }^{46}$ "In the depths of our hearts we were all guided by the idea that at the end of every war comes a time when tensions are relaxed; at that moment our soldiers could unfurl their flag and make their political demands." ${ }^{77}$ Those who lobbied for the Division's creation considered this to be a decisive argument. They viewed rhetorical support for a united front with Hitler's forces as merely a concession to the political conjuncture, a way of selling their case to the Germans by arguing the need for the common struggle against bolshevism and the USSR. ${ }^{48}$ In other words, the "strong" ideology was the call for national liberation and the "weak" one, the celebration of an alliance with Germany, was merely a cover.

The extensive and almost completely unexplored memoir literature produced by members and sympathizers of the Division often mentions two scenarios that were uppermost in the minds of soldiers. One envisioned the war exhausting both the Western Allies and the USSR. A second focused on the expectation that after Germany's defeat the democratic West would open a new front against Stalin's totalitarian rule.

43 Vasyl Veryha, Za ridnyi krai, za narid svii, abo Khto taki dyviziinyky? [For Native Land, for One's Own Nation, or Who are Members of the Division?] (Kyiv: Vydavnytstvo imeni Oleny Telihy, 2006), 6.

Marsheruiut dobrovoltsi, Yak kolys ishly striltsi. Hraiut ikh sholomyv sontsi, Usmikh voli na lytsi. Khto zhyvyi, khto zhyvyi, V riad stavai, v riad stavai, Vyzvoliaty-zdobuvaty Ridnyi krai. Kost Pankivskyi, Roky nimetskoi okupatsii [The Years of the German Occupation] (New York; Toronto: Kliuchi, 1965), 216.

46 Pankivskyi, Roky nimetskoi okupatsii, 216.

47 Pankivskyi, Roky nimetskoi okupatsii, 220.

48 For appeals already in 1941 to Hitler and the Germans to allow for the creation of a Ukrainian armed force see: Pankivskyi, Roky nimetskoi okupatsii, 217-21. 
In both scenarios, it was felt, the existence of a trained army would be of great value to Ukrainians and potentially crucial in a struggle for independence.

A second, related argument focused on the inevitability of recruitment to the German army for military service. The Germans, it was said, were already conscripting men into their armed forces and were preparing to form a division out of Ukrainians, who were volunteering in significant numbers to fight the USSR. ${ }^{49} \mathrm{~A}$ number of political leaders felt that in these circumstances it was better to develop a cohesive unit with a Ukrainian identity under Ukrainian command. Neither the Ukrainskyi Kraiovyi Komitet (Ukrainian Homeland Committee, UHC) in Lviv, nor the Ukrainskyi Tsentralnyi Komitet (Ukrainian Central Committee, UCC) in Kraków had supported the recruitment of Ukrainians to the Waffen-SS in Galicia at the end of 1941. Nonetheless, in spite of this opposition on the part of Ukrainian community leaders, this first recruitment drive was able to attract about 2,00o men (from supposedly racially appropriate individuals in the regions of Podillia, Pokuttia and Hutsulshchyna), who were sent to various German units. These men were seen by the community's leaders as lost to the national cause because they had become servants of a foreign master. ${ }^{50}$

When in late 1942 Otto von Wächter, the Governor of Galicia, began to promote the idea of Galicia's separation from the Generalgouvernement, he lobbied for the creation of a separate armed force, hoping that Galicia would provide the trampoline for the further advancement of his own political career and his personal rule over most of Ukraine. ${ }^{51}$ In 1943, wartime German losses had led to the loosening of the requirement that only "racially pure" men be accepted into the army. First Estonian and Latvian, and then other divisions were formed: Belarusian, Uzbek, Bosnian, and many others. Wächter's overtures to the UHC and UCC made it clear that a Division would be created even without their approval. These committees took a decision to support the Division's creation, but simultaneously tried to win as many concessions from the Germans as possible. Pankivskyi has argued:

Without exception leading circles in Warsaw, Prague and Berlin viewed the creation of an armed formation positively. No responsible agent in our national life was against the Division's creation. [The former] President A[ndrii] Levytskyi and the military agents in the State Centre of the Ukrainian People's Republic,

49 There were already Ukrainians in the German armed forces. The Ukrainske Vyzvolne Viisko (UVV) was an army similar to the ROA, with its own name but not its own commanders. It was made up of various military and security sections throughout the entire front. All together they counted about 180,00o, wore German uniforms, but for identification they had on the left sleeve a shield of light blue with an embroidered gold and the letters UVV. David Littlejohn, The Patriotic Traitors: A History of Collaboration in German Occupied Europe, 1940-1945 (London: Heinemann, 1972), 328.

$50 \quad$ Pankivskyi, Roky nimetskoi okupatsii, 221.

$51 \quad$ Pankivskyi, Roky nimetskoi okupatsii, 221. 
the leaders of our former political parties, all the bishops with Metropolitan Sheptytskyi at their head, evaluated the creation of Ukrainian armed forces in the struggle with Moscow, albeit in the narrow and distorted form of a "Galicia" Division, as a serious and valuable political trump card. ${ }^{52}$

According to Pankivskyi, the leadership of both wings of the OUN opposed the idea, because not they but the UCC would be seen as the Division's co-creator. ${ }^{53}$ However, internally both wings of the OUN were split. In each case the rank-and-file did not share the leadership's views, "something that became clear from the large number of volunteers who came from both wings." ${ }^{54}$ For this reason, the leadership later revised its negative view, and even claimed to have instructed youth to enroll. ${ }^{55}$

The UCC stipulated certain conditions for supporting the Division's creation: (a) it had to have a Ukrainian character as reflected in its name, insignia and commanding officers; (b) it had to be part of the Wehrmacht, because the Waffen-SS were not allowed religious care; (c) it had to be fully mechanized, with tanks and planes, and should not serve as mere cannon fodder; (d) it should, as a whole and in its parts, only be used on the front in the struggle against Bolshevik forces.

In the end, according to Pankivskyi, "only a small number of our demands were met." ${ }^{6}$ The Division was given the name "Galicia" and the insignia of a lion with three crowns, which dated to Austrian times. The demand was rejected for the trident to be used as the insignia. The commanding officers were "temporarily" to be Germans; Ukrainians were not allowed to serve any higher than at the rank of captain. The Division was included in the Waffen-SS because, it was argued, only auxiliary brigades (Hiwis) were allowed into the Wehrmacht. However, one main principle of the WaffenSS formations, the lack of spiritual care, was broken. Almost uniquely, the Division was assigned chaplains. Moreover, it was formed as a semi-mechanized force, a Grenadier division. ${ }^{57}$

Some other demands were not met at all. One was the call to release political prisoners and officers of the former pro-OUN(B), or Banderite, Legion Nachtigall. It had been used in Belarus in 1942 against Soviet partisans, but had then revolted and its officers had been imprisoned. Other unfulfilled demands included amnesty for deserters from the work brigades, both in Germany and at home; improvement in the 
situation of the Ukrainian police; permission for the Ukrainske Vydavnytstvo (Ukrainian Publishers) to run its press in Galicia; and an easing of the economic situation. ${ }^{58}$

Some demands were met only at the end of the war. Shortly before capitulation the Division was assigned Ukrainian senior officers and was formally identified as a separate Ukrainian entity - the 1st Ukrainian Division of the Ukrainian National Army. General Pavlo Shandruk was appointed as its commanding officer. A couple of demands were fulfilled to a significant degree. Throughout its existence the Division was deployed on the eastern front against Soviet and pro-Soviet partisans and the Red Army; and cadres of Ukrainian officers were created through training programs. ${ }^{59}$ When deployed at the front, the Division was subordinated to the Wehrmacht's command, which decided which units were to be attached to it, and how they were to be deployed. Normally, Waffen-SS units, which had received better training, were sent into battle at critical places on the front.

The Division's political importance was tacitly recognized. Metropolitan Andrei Sheptytskyi, head of the Ukrainian Greek Catholic Church, provided it with chaplains. These gave the formation a distinct Ukrainian character and their presence counteracted Nazi propaganda. Sheptytskyi in all probability agreed that a national military force would be invaluable in the chaotic situation that was expected to follow the German collapse. ${ }^{60}$ The Division was seen as potentially important for keeping order and defending the population in the wake of the German retreat. Rev. Vasyl Laba, who was a member of the Military Administration (Viiskova Uprava), the body that tried to strengthen the Division's liaison with the community, was first tasked by Sheptytskyi with supporting the recruits and then appointed as a chaplain in the Division. Otto Wächter, who like the rest of the German authorities had until that moment ignored the Ukrainian Catholic Church, met with its leaders and asked them to provide chaplains. The hierarchy was in a difficult position. It did not want to refuse the request from officers and soldiers for spiritual care, but at the same time it did not want to send its priests into the areligious German SS milieu. Nor did it want a decision to provide spiritual care to be interpreted as granting approval for the Division's creation. For Metropolitan Sheptytskyi this was a difficult decision. He had a clear idea about the situation in which the Germans found themselves and foresaw their defeat. However, priests were already visiting the recruits at their training ground in Heidelager (Pustkov, near Debice) to serve mass, give sermons, and provide counsel. The Metropolitan received numerous letters, requests and delegations from the soldiers. Although he challenged the Division's organizers for "associating themselves with bankrupts," he was moved by the appeals of soldiers and appointed Rev. Laba as the vicar overseeing spiritual matters both in the Division and in similar services (such as among the youth

58 Pankivskyi, Roky nimetskoi okupatsii, 227.

59 Michael James Melnyk, To Battle. The Formation and History of the 14th Galician Waffen-SS

Division (Solihull: Helion and Company, 2002), 61-68; Heike, The Ukrainian Division “Galicia," 19-24.

6o Khromeychuk, “Undetermined” Ukrainians, 59. 
that had been drafted or among the men who had been appointed to guard military objects). In all, twenty priests were attached to the Division. ${ }^{61}$

This second narrative has argued that members of the Division were motivated by patriotism, that they were in fact what one historian has called "patriotic traitors" - a group determined to obtain the military know-how their country required by serving a hostile force, but ready to turn against this force at the appropriate time.

\section{Submerged Narratives}

There is a third narrative, one that is neither condemnatory nor heroic, but has considerable explanatory value. In the spring of 1944, during a time when the front stabilized for a few months, as many witnesses have indicated there were few alternatives available to young men who were in the line of the Red Army's advance. They could disappear into the woods to join the Ukrainian Insurgent Army (UPA), something the Bandera wing of the OUN encouraged, but there they would have to conduct antiSoviet and anti-German guerilla warfare with almost no training or support. Another alternative was to work for the German Baudienst, serving German industries, where they would have to survive slave-like conditions and Western bombing. A third was to remain in hiding until the Soviets came and then be forcibly mobilized into the Red Army. This last alternative not only meant fighting for the detested collective farms, NKVD, and Stalin's dictatorship. It also meant being put on the front lines and driven into battle with poor equipment and only a few days of preparation. This "punishment" for living under occupation was suffered by many, and resulted in enormous casualties. The Germans, who were aware that this fate awaited any young men left behind after their retreat, began capturing able-bodied youth and sending them to work in Germany. Under these conditions, many saw volunteering for the Division simply as their best chance of surviving the war. This consideration was probably an important one for numerous individuals who joined or allowed themselves to be conscripted at this time, during the second wave of recruitment in 1944.

The situation was further complicated by the fact that the Polish government-inexile had denounced the creation of the Division and threatened severe punishment for anyone who joined it. Polish underground cells attempted at the time to sabotage

61 Vasyl Laba, "Dukhovna opika nad striltsiamy 1-oi UD," Visti Bratstva kol. Voiakiv 1 UD UNA 10-11 (October - November 1952): 7-8. The priests were Vasyl Laba, Roman Lobodych, Severyn Saprun, Mykhailo Levenets, Yosyp Karpynskyi, Vasyl Leshchyshyn, Yosyf Holoida, Yosyp Kladochnyi, Volodymyr Stetsiuk, Vsevolod Ivan Durbak, Emanuil Korduba, Danylo Kovaliuk, Sydir Nahaievskyi, Bohdan Levytskyi, Liubomyr Syvenkyi, Oleksandr Babaii, Oleksandr Markevych, Mykhailo Ratushynskyi, Yuliian Gabrusevych, Ivan Tomashivskyi. A number of these men accompanied the dyviziinyky from training camp, to front line service, to internment abroad. Laba reports that they were generally treated with respect by German authorities. Volodymyr Stetsiuk, however, was shot and killed near Brody by an SS officer. Laba, "Dukhovna opika nad striltsiamy 1-oi UD," 8. 
the recruitment. Although the attitude of German military authorities was positive, local German administrations viewed Ukrainians with suspicion and sometimes tried to convince Himmler that the Division would at the first opportunity turn against the Germans, as had happened in 1918 at the end of the First World War.

The three main narratives outlined above do not, of course, exhaust the various attitudes toward the Division's history, or the considerations that motivated soldiers. There are further important narrative lines in both the scholarly and popular press. One concerns the British decision to transport the Division to the UK and then to give its members civilian status. UK officials argued that most members of the Division had signed up out of patriotic motivation, although, as one might expect, these officials were aware that the range of motives was wide. ${ }^{62}$ As has been suggested, this motivation might have included the desire to fight communism, to avoid conscription into another force, to escape responsibility for past actions, or simply to survive. Soldiers of the Galicia Division were only accepted after a precedent had been set by a decision in March 1950 to allow former Waffen-SS Volksdeutsche to enter the UK. By then the political atmosphere had changed. The Cold War had begun and the profile of the Division's soldiers as nationalist fighters determined to oppose the Red Army was regarded favorably. This discussion was influenced by postwar politics, especially by the revision of attitudes toward Germany and the immediate past.

\section{Unexplored Topics}

There exist a number of other topics, an exploration of which would further complicate simplistic depictions of the Division and its members. The individual lives of Division members, which have been recorded in the rich memoir literature, have rarely been discussed in the scholarly literature. The experience of these men, whether in pre-war Poland and Ukraine, in Soviet and German prison camps, or in military formations, rewards study. During the war, some had fought in the Red Army and had then been imprisoned when they succeeded in making their way back from behind German lines, mainly because Stalin had decreed that no soldier was to retreat. A number of these men then ended up in German prisoner-of-war camps, where they were given the choice of joining the Division or starving.

The complexity of their life stories and the difficult choices they faced have not yet been analyzed. It has, for example, often gone unrecognized that about ten percent of the Division's soldiers were from Central and Eastern Ukraine. Some had served in the Red Army, other had experienced Germany as slave laborers. The story of deserters from the Division has also rarely been told. Remarkably, a number of these men went on to serve in the anti-German resistance in France, and then had careers in the French, British, US, and other armies.

Another fascinating and unexplored episode concerns the Division's imprisonment in British camps. After it surrendered to the British in Italy in May 1945, its members 
were interned in POW or SEP (Surrendered Enemy Personnel) camps, first in Rimini on the Italian coast, and then in the United Kingdom. After their release in 1948-1949, the Division's soldiers settled in Britain, Canada, Australia, and other countries. A substantial part of the memoir literature describes life in the camps. It sheds light on who the soldiers were, how they developed a "patriotic" and national liberation narrative at this time, partly in opposition to the Soviet repatriation commission that tried to convince them to return. This literature also describes their relations with the British, Canadians, Germans, Italians, Poles, Russians, and other groups. Life in Rimini was marked by solidarity and self-education. There were schools, university-level courses, classes in language- and skills-training, public lectures, a press and publications, a theatre, an art group, choirs, a jazz group, an orchestra, sports clubs and events, churches, and a range of activities including concerts. The churches, equipment, clothing, art works, and instruments were ingeniously constructed by the former soldiers out of available materials. The performance groups acted as the Division's ambassadors in the wider world, with the choir in particular enjoying great success. It was invited to tour other camps and various towns in Italy. These cultural activities and the publicationsnewspapers, poetry collections, and novels - helped to develop solidarity and a belief in the group's continuing patriotic mission. The camp was visited by representatives not only from the Soviet Union, but also from Poland, the Vatican, and the Canadian Ukrainian community. All these visitors testified in different ways to the cohesion and sense of political awareness of the internees.

Almost completely overlooked has been the fiction, poetry and memoir literature produced by members of the Division. The first writings appeared in the Rimini camp. Among the more prominent authors were novelists and poets like Vitalii Bender (Donchak, Donchenko, Bon D’Ie), Evstakhii Zahachevskyi, Bohdan Bora, Andrii Lehit, Yurii Forys, Stepan Liubomyrskyi (Rykhtytskyi, Elerson), and Oleksii Zaporozhets (O. Devlad, O., Did Pasichnyk).

Much of the memoir writing was published or republished in the Division's periodicals Visti (News) and Visti kombatanta (Combatant News) over the following half century. It deals not only with the wartime experience, but also with the initial recruitment drive organized by the Ukrainian Central Committee, the work of the Military Administration, the fate of the youth who were not old enough to join the Division but were attached to the Luftwaffe's anti-aircraft defense, and numerous other issues.

Among the more informative memoirs are those that record the Division's experience in POW-SEP camps (Zahachevskyi, Volodymyr Gotskyi, Lev Stetskevych, Natalia Sydorenko), personal odysseys (Bender, Zaporozhets, Veryha, Pavlo Hrytsak, Yevhen Pobihushchyi, Dmytro Ferkuniak, Zynovii Knysh), accounts of battles, and creative literature (Oleh Lysiak, Roman Kolisnyk, Roman Lazurko, Sviatomyr Fostun, Bora). The memoir literature has been acknowledged as "crucial in constructing the image of the Division among the Ukrainian diaspora and in post-Soviet Ukraine." ${ }^{33}$ It is 
in many cases both revealing and nuanced, especially, for example, when it deals with divided loyalties and the attitude of soldiers toward the Germans, the war, repatriation, the West, and international politics.

Finally, one might mention the important topic of changing perceptions among interpretive communities. As archival materials and other sources have become available, these perceptions have continued to transform. Children of Division members have now, for example, contributed some personal histories and have helped to demystify aspects of the history (Nimenko, Rohde). In the context of today's memory wars there is a need both to synthesize the available material, and to contextualize the different ways in which the Division has been remembered. By checking established interpretations against available facts, and by offering new perspectives, it will be possible to better grasp how various narratives have shaped, and continue to shape, cultural memory.

\section{Bibliography}

Armstrong, John A. Ukrainian Nationalism. 2nd rev. ed. New York: Columbia University Press, 1963 .

Bender, Roger James, and Hugh Page Taylor. Uniforms, Organization and History of the Waffen-SS. San José, CA: R. James Bender Publishing, 1975.

Bolianovskyi, Andrii. Dyviziia "Halychyna". Istoriia [The Galicia Division: A History]. Lviv: IU, 2000.

Calvocoressi, Peter. Nuremberg: The Facts, the Law and the Consequences. London: Chatto and Windus, 1947.

Deschènes, Honourable Jules. Commission of Inquiry on War Criminals. Report. Part 1: Public. Ottawa: Canadian Government Publishing Centre, 1986.

Dolynskyi, Roman. “Boiova hrupa Baiersdorfa [The Bayersdorf Military Group].” Visti Bratstva kol. Voiakiv 1. UD UNA (Munich) 3-8 (1957): 77-8o, and 7-10 (1957): 6-10.

Dmytruk, Klym. Bezbatchenky: Pravda pro uchast ukrainskykh burzhuaznykh natsionalistiv i tserkovnykh iierarkhiv u pidhotovtsinapadu fashystskoi Nimechchyny na SRSR [Fatherless: The Truth about the Participation of Ukrainian Bourgeois Nationalists and Church Hierarchs in the Preparation of the Attack of Fascist Germany on the USSR]. Lviv: Kameniar, 1974.

Dmytruk, Klym. Svastyka na sutanakh [Swastika on Cassocks]. Kyiv: Vyd-vo polit. lit-ry, 1973.

Ferkuniak, Dmytro. Spomyny z zhyttia v Dyvizii "Halychyna" iv poloni 1943-1947 [Memoirs on Life in the Galicia Division and in Captivity, 1943-1947]. Ivano-Frankivsk: Lileia$\mathrm{NV}, 2003$.

Heike, Wolf-Dietrich. Sie wollten die Freiheit. Die Geschichte der Ukrainischen Division 1943-1945. Dorheim: Podzun, 1973.

Heike, Wolf-Dietrich. The Ukrainian Division "Galicia," 1943-45: A Memoir. Toronto: Shevchenko Scientific Society, 1988. 
Heike, Wolf-Dietrich. Ukrainska dyviziia "Halychyna": Istoriia formuvannia i boiovykh dii u 1943-1945 rokakh [Ukrainian Galicia Division: History of its Creation and Military Operations, 1943-1945]. Toronto: Bratstvo kolyshnikh voiakiv 1-oi ukrainskoi dyvizii UNA, 1970.

Hrytsak, Pavlo. Vezhi i kulemety (Spohady z Dyvizii i bolshevytskoho polonu) [Towers and Machine Guns (Memoirs about the Division and Bolshevik Captivity)]. Munich: Bratstvo kol. voiakiv 1-oi Ukrainskoi Dyvizii UNA, 1959.

Khromeychuk, Olesya. "The Shaping of 'Historical Truth': Construction and Reconstruction of the Memory and Narrative of the Waffen SS 'Galicia' Division." Canadian Slavonic Papers 54.3-4 (2012): 61-86.

Khromeychuk, Olesya. "Undetermined" Ukrainians. Post-War Narratives of the Waffen SS “Galicia” Division. Bern: Peter Land, 2013.

Knysh, Zynovii. Za chuzhu spravu (Rozpovid Mykhaila Koziia z sela Bohdanivka, povit Skalat, yoho pryhody v bolshevytskomu poloni i u polskii armii henerala Andersa) [For a Foreign Cause (The Story of Mykhailo Kozii from the Village Bohdanivka, Skalat District, His Adventures in Bolshevik Captivity and in the Polish Army of General Anders)]. Paris: Natsionalistychne vydavnytstvo v Yevropi, 1958.

Kolasky, John. The Shattered Illusion: The History of Ukrainian Pro-communist Organizations in Canada. Toronto: PMA Books, 1979.

Kolisnyk, Roman. "Protokoly viiskovoi upravy (Dyvizii 'Halychyna') 1943-1947. [Divisional Records 1943-1947. Minutes of Meetings]." Ukrainian Canadian Research and Documentation Centre, Toronto. 2015.7. A, 17-21.

Kolisnyk, Roman. Viiskova Uprava ta ukrainska Dyviziia Halychyna [The Military Administration and the Ukrainian Galicia Division]. 2d rev. ed. Kyiv: Naukove tovarystvo im. Shevchenka v Kanadi; Yaroslaviv val, 2009.

Lazurko, Roman. Na shliakhakh Yevropy [On the Path of Europe]. Chicago: Bratstvo kolyshnikh Voiakiv 1 UD UNA, 1971.

Littlejohn, David. The Patriotic Traitors: A History of Collaboration in German Occupied Europe, 1940-1945. London: Heinemann, 1972.

Lewyckyj, B. “Ukraińcy a likwidacja Powstania Warszawskiego.” Kultura (Paris) 6 (1952): 74-87.

Littman, Sol. Pure Soldiers or Sinister Legion. The Ukrainian 14th Waffen-SS Division. London: Black Rose Books, 2003.

Littman, Sol. "Transcript of Sol Littman's Tryzub and Swastika Speech, 31 August 1997." Accessed March 7, 2019. http://willzuzak.ca/lp/littma99.html.

Logusz, Michael O. Galicia Division: The Waffen-SS 14th Grenadier Division 1943-1945. Atglen, PA: Schiffer Pub., 1997.

Lysiak, Oleh. Za striletskyizvychai:Roman [In the Custom of Riflemen:A Novel]. Munich: Vydannia Bratstva kol. Voiakiv 1-oi Ukrainskoi Dyvizii UNA, 1953.

Matla, O. "Sprava Huty Pieniatskoi i dzherela [The Huta Pieniacka Case and the Sources]." Visti kombatanta 1.93 (1978): 55-61.

Medvedev, Dmitrii. Silnye dukhom [Strong of Spirit]. Kyiv: Radianskyi pysmennyk, 1963. 
Melnyk, Michael James. To Battle. The Formation and History of the 14th Galician WaffenSS Division. Solihull: Helion and Company, 2002.

Melnyk, Michael James. The History of the Galician Division of the Waffen-SS. 2 vols. Stroud, UK: Fonthill, 2016.

Nimenko, Wasyl. Searching in Secret Ukraine. Hitchin, UK: Goalpaths Books, 2016.

Ortynskyi, Liubomyr. "Persha ukrainska dyviziia na tli politychnykh podii Druhoi svitovoi viiny [The First Ukrainian Division in the Context of Political Events during the Second World War]." Visti kombatanta 5-6 (1986): 5-34.

Ortynskyi, Liubomyr. "Prawda o Ukraińskiej Dywizji." Kultura (Paris) (1952): 109-16.

Pankivskyi, Kost. Roky nimetskoi okupatsii [The Years of the German Occupation]. New York; Toronto: Kliuchi, 1965.

Pobihushchyi, Yevhen [Pobihushchyj-Ren, Colonel Evhen]. Mozaika moikh spomyniv [The Mosaic of My Memoirs]. Ivano-Frankivsk: Lileia-NV, 2003.

Pohl, Dieter. Nationalsozialistische Judenverfolgung in Ostgalizien 1941-1944: Organisation und Durchführung eines staatlischen Massen verbrechens. Munich: R. Oldenbourg Verlag, 1997.

Rodal, Alti. "How Perpetrators of Genocidal Crimes Evaded Justice: The Canadian Story." In Remembering for the Future. The Holocaust in an Age of Genicide, Vol. 1, edited by John K. Roth and Elizabeth Maxwell, 702-25. Basingstoke: Palgrave Macmillan, 2001.

Rodal, Alti. "Nazi War Criminals in Canada: The Historical and Policy Setting from the 1940s to the Present." Unpublished study by the Director of Historical Research, Commission of Inquiry on Nazi War Criminals in Canada (Deschênes Commission), September 1986. Library and Archives Canada, RG33, 1986, Rodal Report; also in Provincial Archives of Ontario, Veryha Collection. F1405-56-139. B 822590.

Rodal, Alti. “The Ukrainian 'Halychyna' (Galician) Waffen-SS Division.” Chapter XII, part 3. Manuscript obtained from author.

Rohde, Matt. When Eternities Met: A True Story of Terror, Mutiny, Loss, and Love in a Disremembered Second World War. Union Bridge, Maryland: Pencil and Barn 2017.

Sprawozdanie sytuacyjne z ziem wschodnich. Ministertwo Spraw Wewnętrrzych. Wydzial Spoleczny. Nos. 12/44 and 15/44 (April-May, 1944).

Stetskevych, Lev. Yakz Berezhan do Kadry: Spomyny z Dyvizii [From Berezhany to Kadra: Memoirs on the Division]. Ternopil: Dzhura, 1998.

Sydorenko, Natalia. "Taborovi budni viiskovopolonenykh na brytanskykh ostrovakh (1947-1950) [Daily Camp Life of Ukrainian Prisoners of War in the British Isle, 1947-1950]." In Persha ukrainska Dyviziia ukrainskoi natsionalnoi armii: istoriia stvorennia ta natsionalno-politychne znachennia. Materialy Naukovo-praktychnoi konferentsii. Dopovidi ta povidomlennia, 127-46. Lviv: Novyi chas, 2002.

Terlytsia, Marko [Petro Kravchuk]. Here is the Evidence. Toronto: Kobzar Publishing Company Lrd., 1984.

Terlytsia, Marko. Pravnuky pohani: ukrainskinatsionalistyv Kanadi [Bad Grandchildren: Ukrainian Nationalists in Canada]. Kyiv: Radianskyi pysmennyk, 196o. 
Torzecki, Ryszard. Review of Dorohamy Druhoi Svitovoi Viiny: Lehendy pro uchast ukraintsiv $v$ Varshavskomu povstanni 1944 r. ta pro Ukrainsku dyviziiu 'Halychyna,' by Vasyl Veryha. Dzieje Najnowsze 123.4 (1981): 206-11.

Veryha, Vasyl. Dorohamy Druhoi svitovoi viiny: Legendy pro uchast ukraintsiv $u$ Varshavskomu povstanni 1944 r. ta pro Ukrainsku Dyviziiu "Halychyna" [On the Paths on the Second World War: Myths about the Participation of Ukrainians in the Suppression of the Warsaw Uprising and the Ukrainian Galicia Division]. 2nd rev. ed. Toronto: Shevchenko Scientific Society in Canada, 1981. (3rd rev. ed. Np [Toronto]: Kanadske naukove tovarystvo im. Shevchenka, Nakaldom Bratstva kol. Voiakiv I-oi UD UNA, 1998.)

Veryha, Vasyl. The Correspondence of the Ukrainian Central Committee in Cracow and Lviv with the German Authorities, 1939-1944. Vol. 1. Edmonton: Canadian Institute of Ukrainian Studies, 2000.

Veryha, Vasyl. Za ridnyi krai, za narid svii, abo Khto taki dyviziinyky? [For Native Land, for One's Own Nation, or Who are the Division Members?]. Kyiv: Vydavnytstvo imeni Oleny Telihy, 2006.

Zahachevskyi, Evstakhii. Beliariia, Rimini, Anhliia [Beliariia, Rimini, England]. Chicago; Munich: Bratstvo kolyshnikh Voiakiv 1 UD UNA, 1968.

Zahachevskyi, Evstakhi. Spohady frontovyka: Odyseia siroho "koliaboranta" [Memoirs of a Front-line Soldier: The Odyssey of an Ordinary "Collaborationist"]. Munich: Bratstvo kol. voiakiv 1-oi Ukrainskoi Dyvizii UNA, $195^{2}$.

Zaporozhets, Oleksii [O. Devlad, O., Did Pasichnyk]. "Zaklyk 'dodomu': spohad z anhliiskoho polonu [The Call of Home: Memoirs from English Captivity].” Visti Bratstva kol. Voiakiv 1 UD UNA 12 (1952): 3-5.

\section{Selected Archival Sources}

LAC — Library and Archives of Canada, Ottawa

PAO - Provincial Archives of Ontario, Toronto

PISM — Polish Institute and Sikorski Museum, London

PRO — Public Records Office, London

UCRDC_-Ukrainian Canadian Research and Documentation Centre

Myroslav Shkandrij is professor emeritus at the Universities of Manitoba, where he taught Slavic studies in the Department of German and Slavic. His research has focused on issues in Ukraine's history, such as the "cultural renaissance" of the 1920s, the avant-garde, nationalism, Russian-Ukrainian relations, Jewish-Ukrainian relations, and the revolutionary upheavals of the last hundred years. His most recent book are Ukrainian Nationalism: Politics, Ideology, and Literature, 1929-1956 (2015), Avant-Garde Art in Ukraine: Contested Memory, 1910-1930 (2019), and Revolutionary Ukraine 1917-2017: Flashpoints in History and Contemporary Memory Wars (2019). 